\title{
Satellite remote sensing of Asian aerosols: a case study of clean, polluted, and Asian dust storm days
}

\author{
K. H. Lee ${ }^{1}$ and Y. J. Kim ${ }^{2}$ \\ ${ }^{1}$ Department of Satellite Geoinformatics Engineering, Kyungil University, Geongsan, 712-701, Republic of Korea \\ ${ }^{2}$ Advanced Environmental Monitoring Research Center, Department of Environmental Science and Engineering, \\ Gwangju Institute of Science and Technology, 1 Oryong dong, Buk-gu, Gwangju, 500-712, Republic of Korea
}

Received: 30 March 2010 - Published in Atmos. Meas. Tech. Discuss.: 24 June 2010

Revised: 2 December 2010 - Accepted: 2 December 2010 - Published: 20 December 2010

\begin{abstract}
In East Asia, satellite observation is important because aerosols from natural and anthropogenic sources have been recognized as a major source of regional and global air pollution. However, retrieving aerosols properties from satellite observations over land can be difficult because of the surface reflection, complex aerosol composition, and aerosol absorption. In this study, a new aerosol retrieval method called as the Moderate Resolution Imaging Spectroradiometer (MODIS) satellite aerosol retrieval (MSTAR) was developed and applied to three different aerosol event cases over East Asia. MSTAR uses a separation technique that can distinguish aerosol reflectance from top-ofatmosphere (TOA) reflectance. The aerosol optical thickness (AOT) was determined by comparing this aerosol reflectance with pre-calculated values. Three case studies show how the methodology identifies discrepancies between measured and calculated values to retrieve more accurate AOT. The comparison between MODIS and the Aerosol Robotic Network (AERONET) showed improvement using the suggested methodology with the cluster-based look-up-tables (LUTs) (linear slope $=0.94, R=0.92$ ) than using operational MODIS collection 5 aerosol products (linear slope $=0.78, R=0.87$ ). In conclusion, the suggested methodology is shown to work well with aerosol models acquired by statistical clustering of the observation data in East Asia.
\end{abstract}

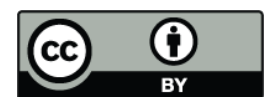

Correspondence to: $\mathrm{K}$. H. Lee (khlee@kiu.ac.kr)

\section{Introduction}

Atmospheric aerosols originate either from natural sources (dust, volcanic, or sea salt, etc.) or from anthropogenic sources (fires, sulfates, soot, etc.). Due to their very high spatio-temporal variability and various optical properties, they are one of the main sources of uncertainty in climate change caused by human activities (IPCC, 2007). Observation from satellites, being global and quasi-continuous, has been a major tool for aerosol studies. Various satellite remote sensing techniques in the visible wavelengths range have been widely used to characterize aerosols and their effect on solar radiation (King et al., 1999; Lee et al., 2009; Kokhanovsky and de Leeuw, 2009). Not only the knowledge of the microphysical and optical properties of aerosols on the radiative transfer but also the accurate estimation of surface reflectance is needed to retrieve reasonable aerosol characteristics. The uncertainties and discrepancies among different retrieval algorithms have been studied (Kokhanovsky et al., 2007, 2009, 2010; Mishchenko et al., 2007) and some insights were obtained (Jeong et al., 2005; Liu and Mishchenko, 2008; Kinne et al., 2006). However, major improvements in the accuracy and spatial resolution of the satellite products are still required for air quality applications in urban areas (Li et al., 2005).

Aerosol optical thickness (AOT) is a basic optical property derived from many Earth observation satellites such as the Advanced Very High Resolution Radiometer (AVHRR) (Rao et al., 1989; Stowe, 1991), the Moderate resolution Imaging Spectro-radiometer (MODIS) (Kaufman et al., 1997a), the Multi-angle Imaging SpectroRadiometer (MISR) (Diner et al., 1998), and the Sea-viewing Wide Field-of-view Sensor (SeaWiFS) (Gordon and Wang,

Published by Copernicus Publications on behalf of the European Geosciences Union. 
1994; von Hoyningen-Huene et al., 2003), etc. AOT is directly related to the atmospheric aerosol load, which is the principal variable describing the effect of aerosols on radiative transfer in the Earth's atmosphere. Remote sensing of aerosols over land is particularly important because the sources of most aerosols (mainly anthropogenic aerosols) are located in land. It is very useful to identify aerosol sources, understand aerosol transformations in the atmosphere, and estimate the anthropogenic contribution. A major problem in aerosol retrieval over land is that the surface reflectance is not only higher than that over the ocean in general, but it also varies spatially and temporally. An inaccurate surface reflectance estimation of 0.01 can result in an uncertainty of $10 \%$ in AOT estimation (Soufflet et al., 1997; Kaufman et al., 1997b). To date, aerosol retrieval over East Asia has been actively studied due to unique aerosol characteristics in the region. This paper is an attempt along this line.

This study presents an aerosol retrieval based on interactive look-up tables (LUTs). We develop LUTs by means of statistical classification method, which is defined in previous work (Omar et al., 2005). In this classification, aerosol optical properties were obtained from AERONET sun-sky radiometer data archive (AERONET, 2010, http://aeronet. gsfc.nasa.gov). Aerosol retrieval is then processed by a step forward from the classified aerosol models and has the advantage of representing more accurate aerosol properties in the retrieval. The retrieved AOT from the $1 \mathrm{~km}$ resolution MODIS Level 1 calibrated reflectance data using this method is compared with MODIS Level 2 and AERONET AOT measured from the ground for validation.

This paper is organized as follows. Section 2 describes the LUTs construction with cluster analysis and the sensitivity tests. Section 3 describes the data set used to retrieve the AOT and the details of the retrieval algorithm. The results of aerosol retrievals from MODIS and their consistency with AERONET data are discussed in Sect. 4. Finally, conclusions are given in Sect. 5 .

\section{Aerosol models}

Aerosol retrieval based on LUTs highly depends on the aerosol models used in the radiative transfer code. Aerosol models can be acquired from well known global climatology (Shettle and Fenn, 1979; d'Almeda et al., 1991; Hess et al., 1998). Nevertheless, aerosol microphysical and optical properties based on in-situ measurement or sun photometry describe real atmospheric conditions (Dubovik and King, 2000). Since aerosols are mainly originated from transport of local air masses and nonsystematic events such as biomass burning (BB), re-suspension, and human activities, these variations lead to diverse aerosol characteristics. The representative aerosol type at a region of interest can be found by the occurrence of a typical type of aerosol at that location if an adequately large sample is used for calculations.

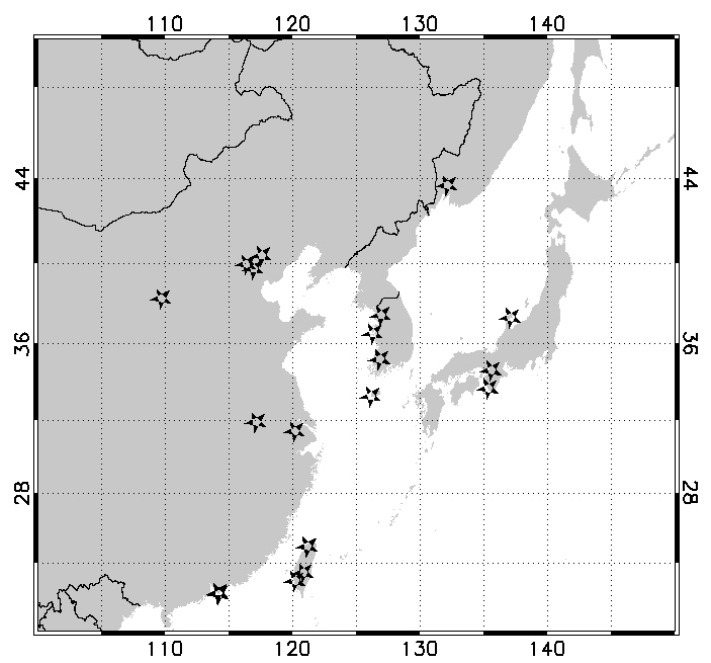

Fig. 1. Map of the study area $\left(20^{\circ}-50^{\circ} \mathrm{N}, 100^{\circ}-150^{\circ} \mathrm{E}\right)$. The rectangular box represents a sub-area for the case study. Twenty AERONET sun-sky radiometer measurement sites are indicated by stars. Geographic locations for each site are available on the AERONET webpage (http://aeronet.gsfc.nasa.gov/).

However, assigning of typical aerosol microphysical and optical properties to a given location based on a long term average has significant shortcomings (Sheridan et al., 2001).

In East Asia, atmospheric aerosols from human activities are recognized as an important source of regional and global pollution (Streets et al., 2003; Wenig et al., 2003). Furthermore, long-range transport of aerosols depends on meteorological conditions and affects air quality over downwind areas. These transported pollutants contain mineral dust as well as aerosol pollution consisting of sulfate, nitrate, and carbonaceous particles (Song et al., 2008). To develop type-specific aerosol models that include aerosol microphysics and optical properties over East Asia, the AERONET database (Holben et al., 1998; Dubovik and King, 2000) having very fine temporal resolution was used. A detailed description of the products is found in the documents of description (see AERONET inversion, 2010; Holben et al., 2006).

The study area of this paper $\left(20^{\circ} \mathrm{N}-50^{\circ} \mathrm{N}, 100^{\circ} \mathrm{E}-\right.$ $150^{\circ} \mathrm{E}$ ), is shown in Fig. 1. Locations of twenty AERONET sites in the study area, Anmyon, Beijing, Chen-Kung_Univ, Gosan, Gwangju, Hefei, Hong Kong Hok Tsui (HKHT), Hong Kong Polytechnic University (HKPU), Jeju, Lulin, National Central University (NCU), Noto, Osaka, Seoul, Shirahama, Taihu, Xianghe, Xinglong, Yulin, and Ussuriysk, are also shown. Post-calibrated and quality assured Level 2.0 AERONET inversion data since 1998, such as AOT, size distribution, single scattering albedo (SSA), asymmetry parameter, refractive indices, etc. are available for grouping large data sets into some categories using the cluster analysis technique (cf. Kaufman and Rousseeuw, 1990; Omar et al., 2005). 
Table 1. Number of cases in each cluster.

\begin{tabular}{lrr}
\hline Cluster & Cases & $\%$ \\
\hline 1 & 688 & 21.4 \\
2 & 184 & 5.7 \\
3 & 1170 & 36.4 \\
4 & 814 & 25.3 \\
5 & 310 & 9.7 \\
6 & 46 & 1.4 \\
\hline Total & 3212 & 100 \\
\hline
\end{tabular}

The six aerosol optical models were defined by an average of the optical properties in each identified cluster. If cluster analysis uses two or three clusters, similar aerosols may lose their unique characteristics and form one or two new clusters. With an increase in the number of clusters, the members of the main clusters remained relatively unchanged. Six clusters provided the largest number of clusters in which each had a reasonable number of categories. The number of cases in each cluster is listed in Table 1. Categories 1, 3, and 4 contained $83 \%$ of the case records and category 2, 5 , and 6 contained the remaining 16.9\%. Therefore, a region of interest may belong to more than one category. Table 2 shows the aerosol and microphysical properties, as well as the number of records for each cluster. Each aerosol model has somewhat different values for refractive indices at particular wavelengths, median particle radius, standard deviation of size distribution, and other optical properties. The aerosol size distribution used in this study is the volume size distribution provided by the AERONET inversion algorithm. The best fit for this size distribution data is a bimodal lognormal size distribution described as follows by Eq. (1),

$$
\begin{aligned}
\frac{d V}{d \ln r} & =\frac{C_{\text {fine }}}{\sqrt{2 \pi} \cdot S_{\text {fine }}} \exp \left[-\frac{\left(\ln R-\ln R_{\text {fine }}\right)^{2}}{2\left(S_{\text {fine }}\right)^{2}}\right] \\
& +\frac{C_{\text {coarse }}}{\sqrt{2 \pi} S_{\text {coarse }}} \exp \left[-\frac{\left(\ln R-\ln R_{\text {coarse }}\right)^{2}}{2\left(S_{\text {coarse }}\right)^{2}}\right]
\end{aligned}
$$

where $C, R$, and $S$ are volume concentration $\left(\mu \mathrm{m}^{3} / \mu \mathrm{m}^{2}\right)$, particle radius $(\mu \mathrm{m})$, and geometric standard deviation, respectively. $R_{\text {fine }}$ and $R_{\text {coarse }}$ denote mean radius for fine and coarse modes. This partition of the size distribution into fine and coarse modes yields six parameters by which the size distribution can be described.

Figure 2 compares the size distribution, SSA, and asymmetry parameter for the six clustered aerosol models. Size distributions show that the values of $\mathrm{dV} / \mathrm{d}$ lnr varied significantly for different categories. Categories 1-4 had larger fine modes as compared to categories 5-6, and SSA values varied from 0.90 to 0.93 at $440 \mathrm{~nm}$. The differences in absorption magnitudes between two categories were attributed to differences in the relative percentages of finer particulates,
Table 2. Summary of aerosol cluster.

\begin{tabular}{lllllll}
\hline & \multicolumn{6}{c}{ Cluster } \\
\cline { 2 - 7 } & 1 & 2 & 3 & 4 & 5 & 6 \\
\hline $\mathrm{SSA}_{441}$ & 0.915 & 0.927 & 0.904 & 0.908 & 0.893 & 0.900 \\
$\mathrm{SSA}_{675}$ & 0.927 & 0.941 & 0.908 & 0.914 & 0.939 & 0.957 \\
$\mathrm{SSA}_{869}$ & 0.918 & 0.933 & 0.897 & 0.907 & 0.945 & 0.964 \\
$\mathrm{SSA}_{1018}$ & 0.912 & 0.928 & 0.889 & 0.903 & 0.948 & 0.966 \\
$m_{441}$ & 1.468 & 1.478 & 1.441 & 1.454 & 1.508 & 1.549 \\
$m_{675}$ & 1.480 & 1.483 & 1.458 & 1.472 & 1.535 & 1.549 \\
$m_{869}$ & 1.485 & 1.483 & 1.468 & 1.482 & 1.536 & 1.537 \\
$m r_{1018}$ & 1.481 & 1.476 & 1.468 & 1.481 & 1.528 & 1.525 \\
$m i_{441}$ & 0.0119 & 0.0099 & 0.0127 & 0.0112 & 0.0070 & 0.0049 \\
$m i_{675}$ & 0.0086 & 0.0074 & 0.0100 & 0.0088 & 0.0037 & 0.0024 \\
$m i_{869}$ & 0.0088 & 0.0078 & 0.0102 & 0.0090 & 0.0036 & 0.0023 \\
$m i_{1018}$ & 0.0091 & 0.0080 & 0.0104 & 0.0092 & 0.0036 & 0.0025 \\
$g_{441}$ & 0.721 & 0.729 & 0.716 & 0.713 & 0.730 & 0.748 \\
$g_{675}$ & 0.664 & 0.685 & 0.654 & 0.655 & 0.693 & 0.714 \\
$g_{869}$ & 0.636 & 0.657 & 0.626 & 0.635 & 0.691 & 0.707 \\
$g_{1018}$ & 0.626 & 0.643 & 0.618 & 0.634 & 0.696 & 0.707 \\
$\left.C_{\text {fine }\left[\mu \mathrm{m}^{3} / \mu \mathrm{m}^{2}\right]}\right]$ & 0.153 & 0.269 & 0.079 & 0.070 & 0.062 & 0.130 \\
$R_{\text {fine }}[\mu \mathrm{m}]$ & 0.219 & 0.257 & 0.192 & 0.177 & 0.162 & 0.208 \\
$S_{\text {fine }}$ & 0.531 & 0.535 & 0.504 & 0.474 & 0.538 & 0.619 \\
$\left.C_{\text {coarse }\left[\mu \mathrm{m}^{3} / \mu \mathrm{m}^{2}\right]}\right]$ & 0.131 & 0.192 & 0.075 & 0.091 & 0.346 & 1.039 \\
$R_{\text {coarse }}[\mu \mathrm{m}]$ & 2.724 & 2.580 & 2.915 & 2.265 & 2.286 & 2.241 \\
$S_{\text {coarse }}$ & 0.583 & 0.568 & 0.618 & 0.656 & 0.594 & 0.531 \\
\hline
\end{tabular}

Subscripts numbers the $441,675,869$, and $1018 \mathrm{~nm}$ wavelengths of the AERONET measurements. " $m r$ " and " $m i$ " are real and imaginary parts of refractive index, respectively. The size distribution parameters, volume concentration $(C)$, median radius $(R)$ and standard deviation $(S)$, are based on a bimodal log normal distribution.

which generally have greater absorption capacities. This indicates that these aerosol types are more likely to experience continental or urban/industrial pollution than other aerosol types. The highest absorption (lowest SSA) was seen for categories 3-4. The absorption for category 5-6 exhibited the strongest spectral dependence for the large coarse mode with similar SSA and asymmetry parameter values. The AERONET inversion algorithm assumes the same absorption value for fine and coarse modes for SSA retrieval. In other words, uncertainty in SSA is lower for the dominant fine or coarse modes than for comparable models such as categories 3-4. In this classification, categories 5-6 are referred to as dusty aerosols. Other categories can be considered a mixed type of pollution.

\section{Sensitivity study}

AOT, one of major parameters affecting the radiative transfer calculations, is the basic output parameter from satellite data retrieval. For finding the theoretical relationship between radiance measured by an optical instrument on a satellite and AOT, the input parameters for radiative transfer code include AOT at $550 \mathrm{~nm}\left(\tau_{550}\right)$, SSA, asymmetry parameter, scattering phase function etc. The quality of these data depends directly on the quality of the retrieved AOT. The purpose of this chapter is to provide the sensitivity of the retrieved AOT 

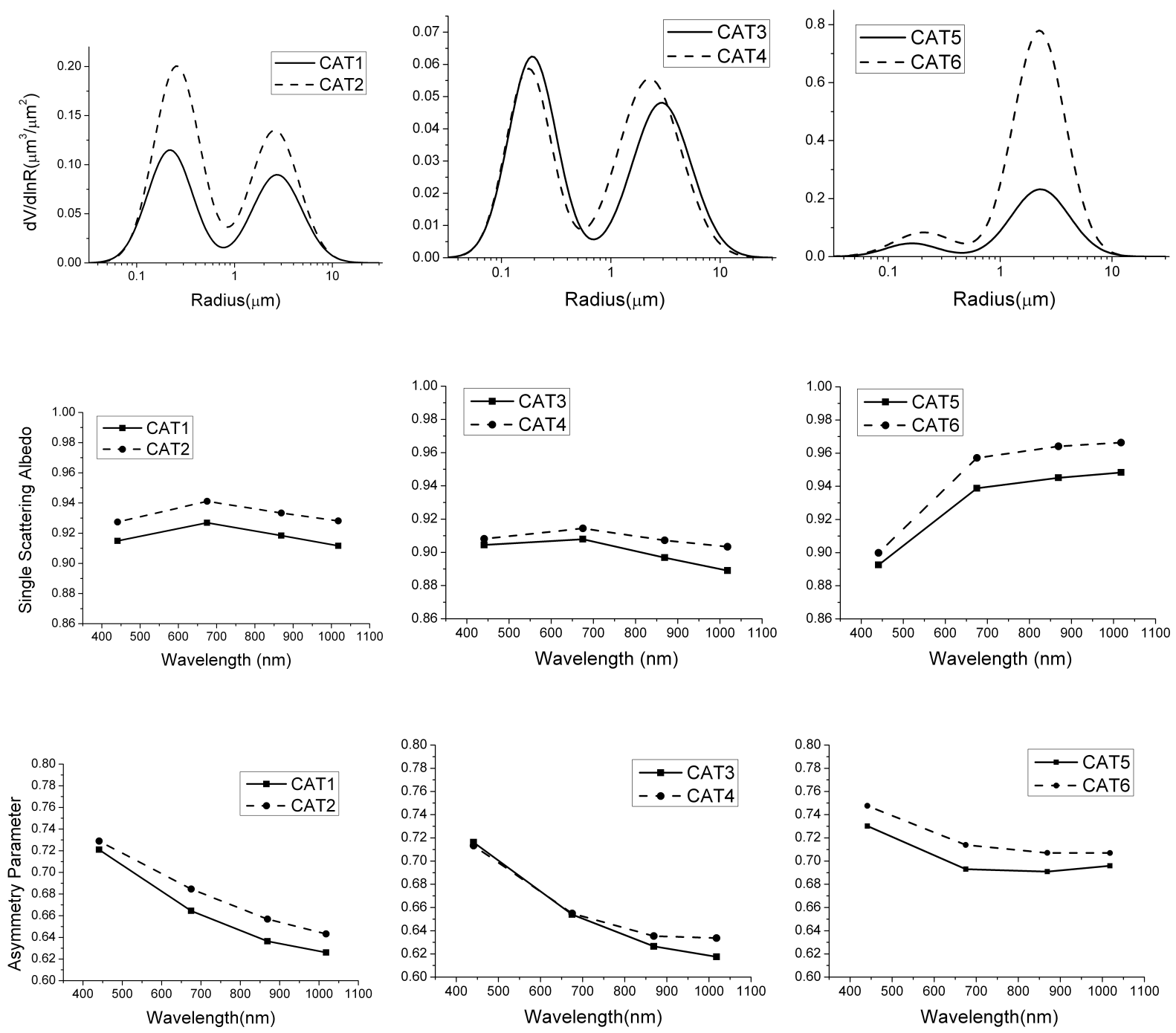

Fig. 2. Optical and microphysical properties of different types of aerosols classified from the AERONET inversion products.

changes with respect to the error-causing input parameters. The sensitivity test results show the importance of accurate information for the SSA, asymmetry parameter, aerosol size distribution, and scattering phase function in the satellite retrieval of AOT.

We ran simulation using the assumed error range of the input parameter and computed the error for the retrieved AOT. A sensitivity study was performed to determine the error impact on each parameter, by comparison with controlled values, which were assumed as SSA $=0.91$ and asymmetry parameter $=0.70$. The term "error" used in this study is the relative mean square error (RMSE).

$$
\Delta \tau_{\varepsilon}=1 / n \sqrt{\sum_{i=0}^{n}\left(\frac{\tau_{\mathrm{C}}-\tau_{\mathrm{ref}}}{\tau_{\mathrm{ref}}}\right)^{2}}
$$

where $\tau_{\mathrm{C}}$ and $\tau_{\text {ref }}$ are the calculated and referenced AOT, respectively, and $n$ is the number of calculations. The terms on the right-hand side of Eq. (2) were estimated by calculating the Santa Barbara discrete ordinance radiative transfer (DISORT) atmospheric radiative transfer (SBDART) (Ricchiazzi et al., 1998) response to realistic errors in the input parameters. Uncertainty in the retrieved AOT from AERONET cluster-based LUTs will definitely affect the accuracy of the data. Figure 3 shows that the error in AOT retrieval increased as a function of the error in SSA and asymmetry parameter.

SSA is an important parameter because it is a source of uncertainty in AOT retrieval. Highly variable SSA in East Asia, typically from 0.88 to 0.97 , highlights the importance of using accurate information for the SSA of 

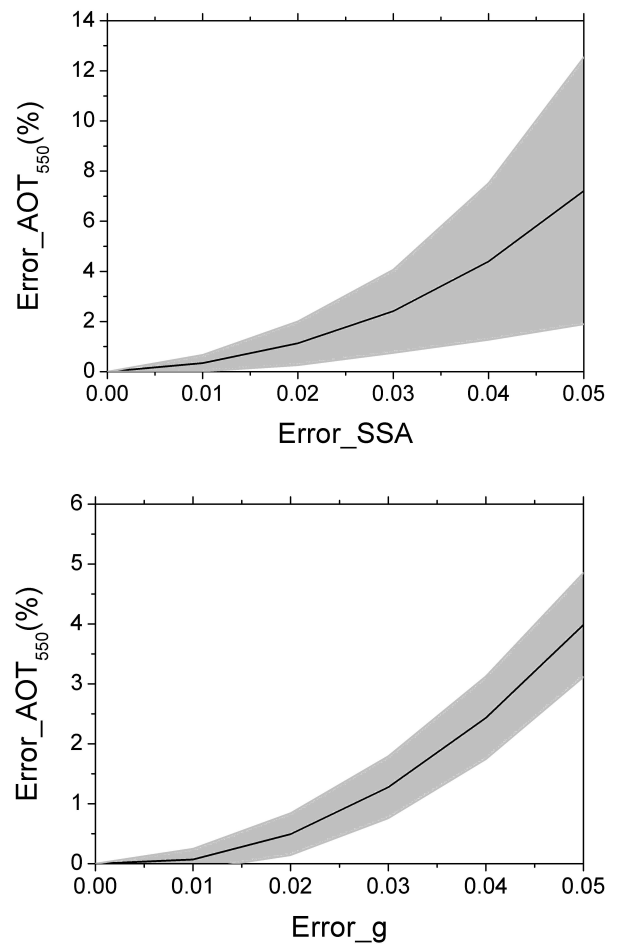

Fig. 3. Percent errors of the retrieved AOT as a function of the error within \pm 0.05 for SSA and \pm 0.05 for $g$ (geometrical inputs are $\theta_{0}=60^{\circ}, \theta_{\mathrm{S}}=0^{\circ}$, and $\varphi=0^{\circ}$ ). The shaded area shows $\pm \sigma$. The valid range of $\mathrm{AOT}_{550}$ is $0-5$.

the aerosol. Because errors in the AERONET-derived SSA were estimated to be $\sim 0.03$ (AOT $>0.2$ ) and $0.05-$ 0.07 (AOT < 0.2) (Dubovik et al., 2000), they were included in our approach. To estimate the AOT retrieval, errors within \pm 0.05 for SSA were applied for radiative transfer simulations. As shown in Fig. 3a, the SSA error could translate to higher AOT retrieval errors because of increased/decreased radiance with increasing/decreasing SSA. This plot can be interpreted as a exponential fit of dAOT $(\%)=0.91043 \cdot \exp (\mathrm{dSSA} / 0.02269)-1.001$ $(R=0.99)$. Therefore, an uncertainty of 0.05 for SSA could cause an uncertainty in the retrieved AOT of $7.2 \%$ for cases studied.

The error caused by asymmetry parameter is also important in the radiative transfer calculations. Uncertainties in the retrieval of asymmetry parameters from AERONET data were in the range of 3-5\% (Andrews et al., 2006). Within this error range, the error ranges within \pm 0.05 were used to estimate the AOT retrieval error. The resulting error was large with respect to the increasing change in asymmetry parameter $(g)$. The exponential fit (Fig. 3b) is $\operatorname{dAOT}(\%)=0.4709 \cdot \exp (\mathrm{d} g / 0.0219)-0.5847(R=0.99)$, and the AOT error caused by asymmetry parameter was substantially lower than that caused by SSA. The value of asymmetry parameter in East Asia varies from 0.72 to 0.76 at
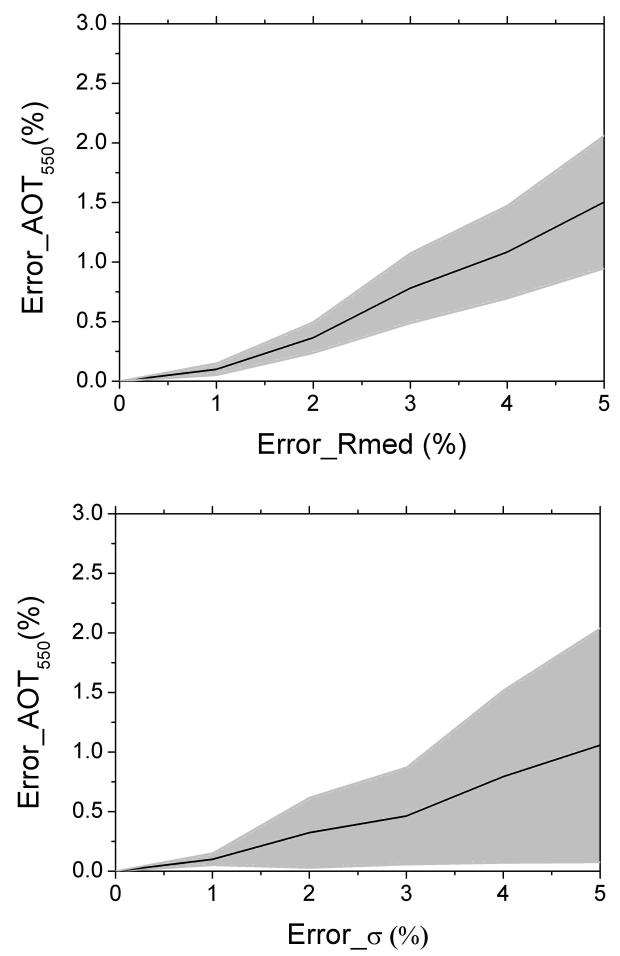

Fig. 4. Percent errors of the retrieved AOT as a function of the error within $1-5 \%$ for median radius and standard deviation for the size distribution function of Eq. (1) (geometrical inputs are $\theta_{0}=60^{\circ}$, $\theta_{\mathrm{S}}=0^{\circ}$, and $\varphi=0^{\circ}$ ). The shaded area indicates $\pm \sigma$. The valid range of $\mathrm{AOT}_{550}$ is $0-5$.

$440 \mathrm{~nm}$; thus a $5 \%$ error $(\sim 0.04)$ of asymmetry parameter can induce an error of $4.04 \%$ in the retrieved AOT.

The aerosol size distribution is another key parameter for characterizing aerosol optical properties. Figure 4 shows the AOT errors $(1 \sim 5 \%)$ in median radius and standard deviation Eq. (1). The AOT errors increased with size distribution error in each plot. Mean error values were $0.75 \%$ for median radius and $0.53 \%$ for standard deviation for cases studied. These values are smaller than those caused by SSA and asymmetry parameter.

Scattering phase function is one of the factors affecting AOT retrievals because it can control directional scattered light. Kokhanovsky et al. (2010) reported the accurate phase function is importance for the accuracy of the aerosol optical thickness estimations using spaceborne observations. Nevertheless, the Henyey-Greenstein (H-G) approximation is often used in atmospheric radiative transfer modeling for its simplicity. H-G approximation has been shown to provide good accuracy when applied to radiative flux calculations (Hansen, 1969) but its parameterization in radiance calculation has less accuracy. Recently, Castanho et al. (2008) used the H-G phase function for their aerosol retrieval to save computation time and the H-G phase function represents the original phase function with the maximum differences of $15 \%$ for 

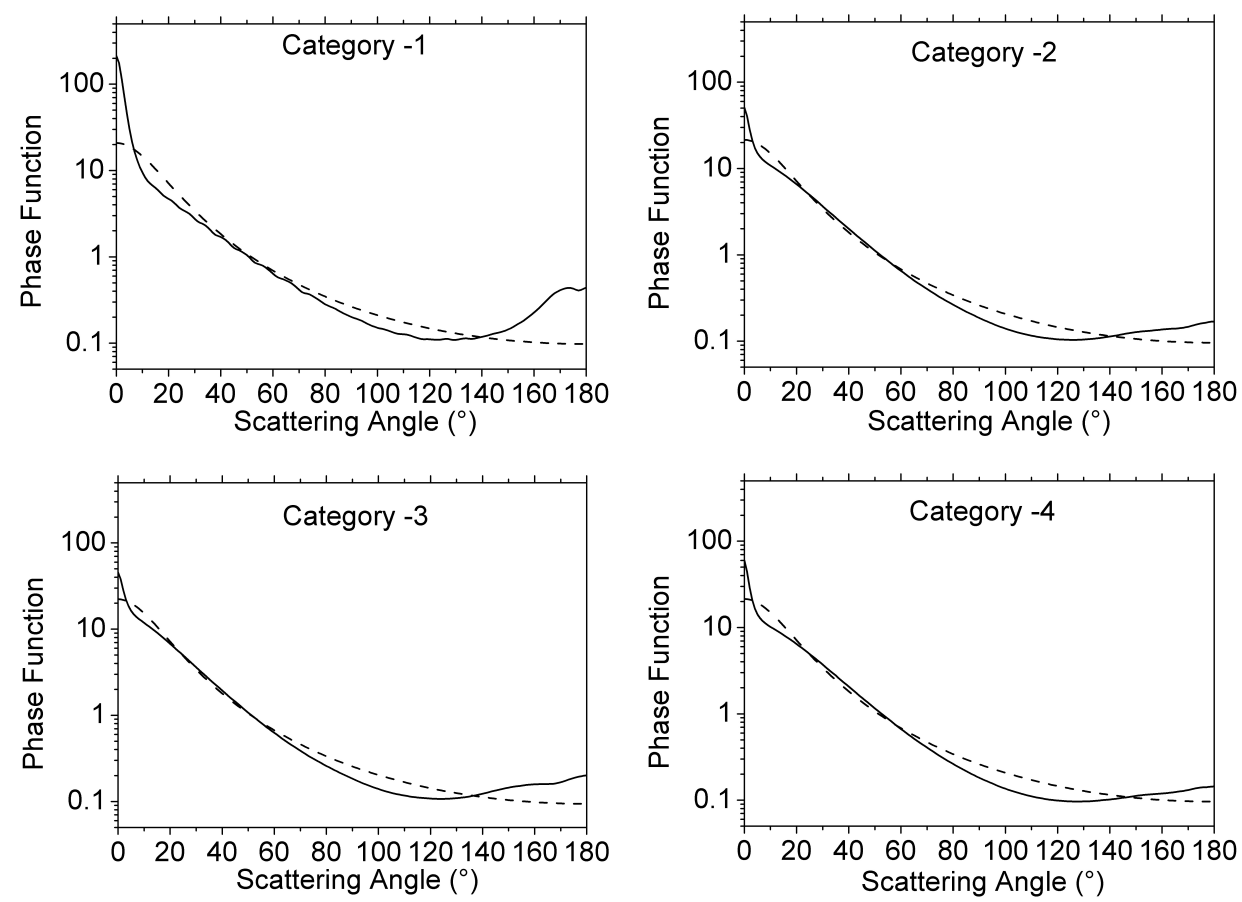

Fig. 5. Mie phase function (solid line) compared with Henyey-Greenstein phase functions (dashed line) for wavelength $=0.47 \mu \mathrm{m}$.

scattering angles between 90 and $180^{\circ}$. Even using this approximation, their retrieval results showed very good correlation with AERONET AOT (linear slope $=\sim 1.06, r^{2}=0.6$ ).

Figure 5 shows a comparison of the Mie phase function at a wavelength of $0.47 \mu \mathrm{m}$ (solid line) with the H-G phase function used in the model simulations having an their asymmetry parameter (dashed line). For a polydispersion, the phase function is taken as the average of all phase functions for each particle radius weighted by the scattering cross section and number density at that radius. Although the H-G approximation can reproduce the forward scattering, it underestimates the amount of scattering at scattering angles larger than $140-150^{\circ}$ in comparison to the Mie phase function. If we compare the modeled spectral reflectance with $\mathrm{H}-\mathrm{G}$ and Mie phase functions, it gives unrealistic errors in the AOT retrieval. However, this number can change in terms of AOT and geometry. Due to the complexity of radiative transfer, we prefer very much to simulate more realistic cases and discuss them in the future study.

\section{Look-up tables}

A LUT was used for aerosol retrieval. LUTs contain several sets of pre-computed reflectance for each of the seven visible channel wavelengths for MODIS $(0.47 \mu \mathrm{m}, 0.55 \mu \mathrm{m}$, $0.66 \mu \mathrm{m}, 0.865 \mu \mathrm{m}, 1.24 \mu \mathrm{m}, 1.63 \mu \mathrm{m}$, and $2.13 \mu \mathrm{m})$. The reflectance in the LUT was computed using clustered aerosol models that represent realistic possibilities for the aerosol properties of a vertical atmosphere column. These aerosol models are based on real measurements involving sun photometer data, as explained Sect. 2. Basically, the LUTs describe the relationships between satellite receiving radiance and the AOT for given atmospheric and surface conditions. In this study, LUTs were calculated using the SBDART code for the retrieval, which can calculate solar flux as well as radiance at different atmospheric heights for the solar illumination and satellite observation geometry. As an input data for SBDART running, $\tau_{550}$, spectral aerosol extinction, SSA, and asymmetry parameter are required for determination of aerosol reflection as a function of AOT. To construct LUTs with different aerosol types, six aerosol models discussed in Sect. 2 were used as input data for SBDART. We used the $\mathrm{H}-\mathrm{G}$ approximation for the phase function, defined in terms of the asymmetry parameter. Spectral aerosol optical properties at seven MODIS visible channel wavelengths were obtained using spectrally interpolated/extrapolated values from AERONET inversion products listed in Table 2.

Example SBDART calculations are shown in Fig. 6. Each curve represents aerosol reflectance as a function of $\tau_{550}$. Under dark surface condition (surface albedo $=0$ ), aerosol reflectance $\left(\rho_{\text {Aer }}\right)$ from SBDART calculations can be formulated as follows:

$\rho_{\text {Aer }}\left(\theta_{0}, \theta_{\mathbf{S}}, \varphi\right)=\rho_{\text {TOA }}\left(\theta_{0}, \theta_{\mathbf{S}}, \varphi\right)-\rho_{\text {Ray }}\left(\theta_{0}, \theta_{\mathbf{S}}, \varphi\right)$

where, $\rho_{\mathrm{TOA}}, \rho_{\text {Ray }}$ are the TOA and Rayleigh reflectance, respectively. $\rho_{\text {Ray }}$ can be obtained when aerosols do not exist $\left(\tau_{550}=0\right)$. $\theta_{0}, \theta_{\mathrm{S}}, \varphi$ are sun zenith angle, satellite viewing 

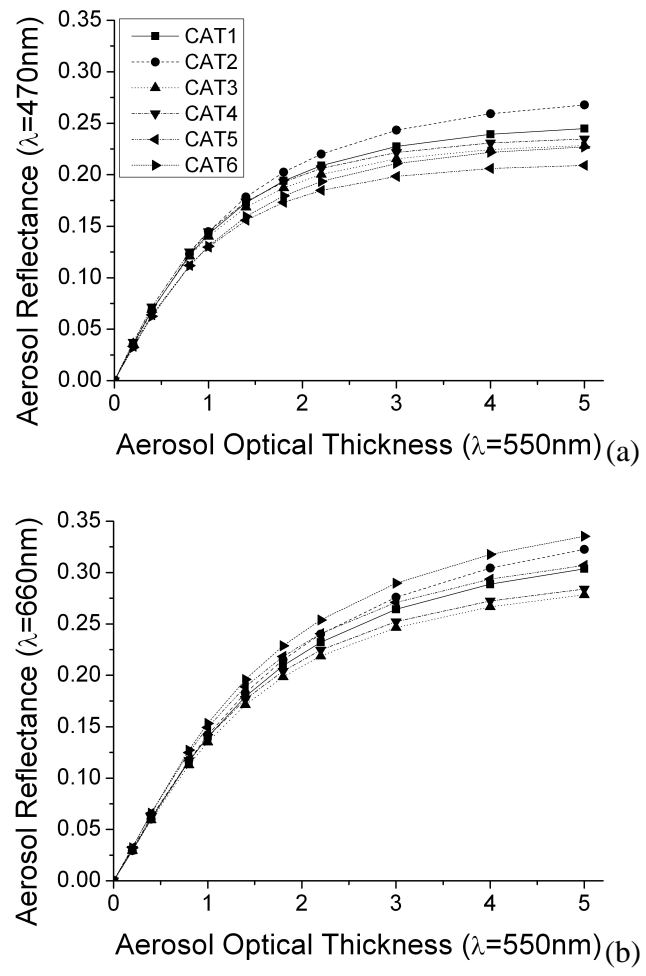

Fig. 6. Aerosol reflectance - (a) $\lambda=470$ and (b) $660 \mathrm{~nm}-$ as a function of AOT at $550 \mathrm{~nm}$, obtained by SBDART calculations with aerosol models from this study (geometrical inputs are $\theta_{0}=60^{\circ}$, $\theta_{\mathrm{S}}=30^{\circ}$, and $\varphi=0^{\circ}$ ). These plots show the increase in aerosol reflectance for different aerosol models with AOT.

angle, and relative azimuth angle between sun and satellite. Reflectance can be calculated by the normalization of radiance $L(\lambda)$ to the extraterrestrial irradiance $F_{0}(\lambda)$ :

$\rho(\lambda)=\frac{\pi \cdot L(\lambda)}{F_{0} \cdot \cos \theta_{0}}$

The LUT was calculated up to an $\tau_{550}$ of $5.0(0.0,0.2$, $0.4,0.8,1.0,1.4,1.8,2.2,3.0,4.0$, and 5.0). Geometrical inputs are $\theta_{0}=0^{\circ} \sim 80^{\circ}\left(\Delta=10^{\circ}\right), \theta_{\mathrm{S}}=0^{\circ} \sim$ $80^{\circ}\left(\Delta=5^{\circ}\right)$, and $\varphi=0^{\circ} \sim 170^{\circ}\left(\Delta=10^{\circ}\right)$, respectively. Therefore, total number of calculation is 6 aerosol models $\times 7$ bands $\times 11$ AOTs $\times 9 \theta_{0} \times 17 \theta_{\mathrm{S}} \times 18 \varphi=1272348$.

Unlike other aerosol models, such as urban- and pollutiondominated aerosols, which are well approximated by equivalent spheres, dusty aerosols are highly irregular in their shapes (see Fig. 9 from Arimoto et al., 2006). Therefore, their optical properties differ significantly from those of spherical particles. Thus, nonspherical phase functions calculated by T-matrix code (Mishchenko and Travis, 1998) for dusty aerosol models (category 5-6) were used in radiative transfer calculations. The spherical particle phase functions produced retrieval artifacts in aerosol retrieval when dust was present (Dubovik et al., 2002a,b). Figure 7 compares the phase functions for categories 5-6 with spherical

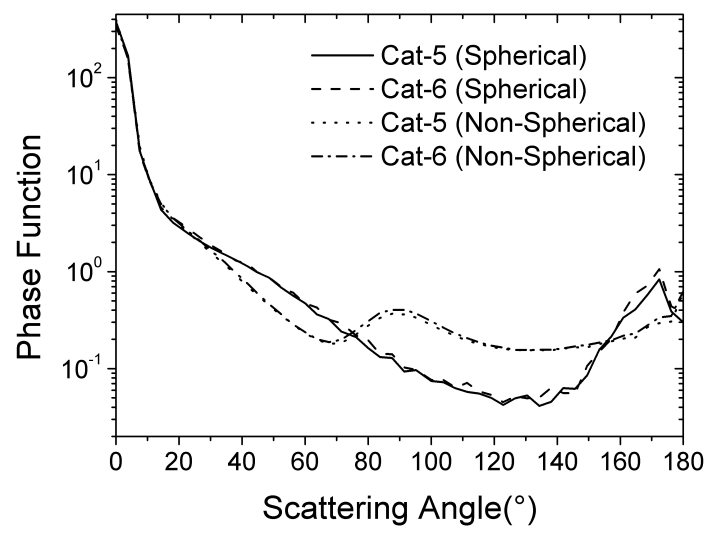

Fig. 7. Scattering phase functions for the dusty aerosol model (categories 5-6) based on the assumption of spherical and non-spherical shapes.

and non-spherical assumptions at $550 \mathrm{~nm}$ wavelength. The difference between the two categories was not significant, but non-sphericity was dominant. The phase function for non-spherical particles shifted upwards in the scattering angle range of $75^{\circ}-155^{\circ}$. In contrast, the phase functions for spherical particles varied significantly in the backward scattering region. For the LUTs with dusty aerosols, TOA reflectance was computed with non-spherical phase functions.

Aerosol reflectance increases strongly with increasing AOT and this increasing rate was variable. Thus, selection of an aerosol model can lead to a high variation in the retrieved AOT. If an algorithm uses an inappropriate aerosol model, the largest differences, $\pm 67 \%$ in the retrieved AOT are anticipated, whereas the real AOT of 4.0 is assumed. However, this is significant for lower AOT $(<0.2)$, where the aerosol reflectance is $\sim 0.03, \pm 0.01(10 \%)$ in the retrieved AOT. Thus, the aerosol model influences the retrieved AOT, and LUTs for different aerosol types are required.

\section{Aerosol retrieval method}

In this study, an aerosol retrieval algorithm over land used the dark target approach (Kaufman et al., 1997a,b), spectral mixing and separation techniques (von Hoyningen et al., 2003, 2010; Katsev et al., 2010), and spectral shape matching (Lee et al., 2007). This is a valid assumption for land surfaces. The method is part of aerosol retrieval procedure for SeaWiFS (Lee et al., 2004) and MODIS (Lee et al., 2007) developed at the Advanced Environment Monitoring Research Center (ADEMRC) of the Gwangju Institute of Science and Technology (GIST), called SaTellite Aerosol Retrieval (STAR). In the algorithm, the blue channel of satellite instrument is used for separation between surface and atmosphere because surface reflectance is relatively low in this spectral region. AOT is then determined by using adequate LUT. However, the use of LUT with wrong aerosol, 


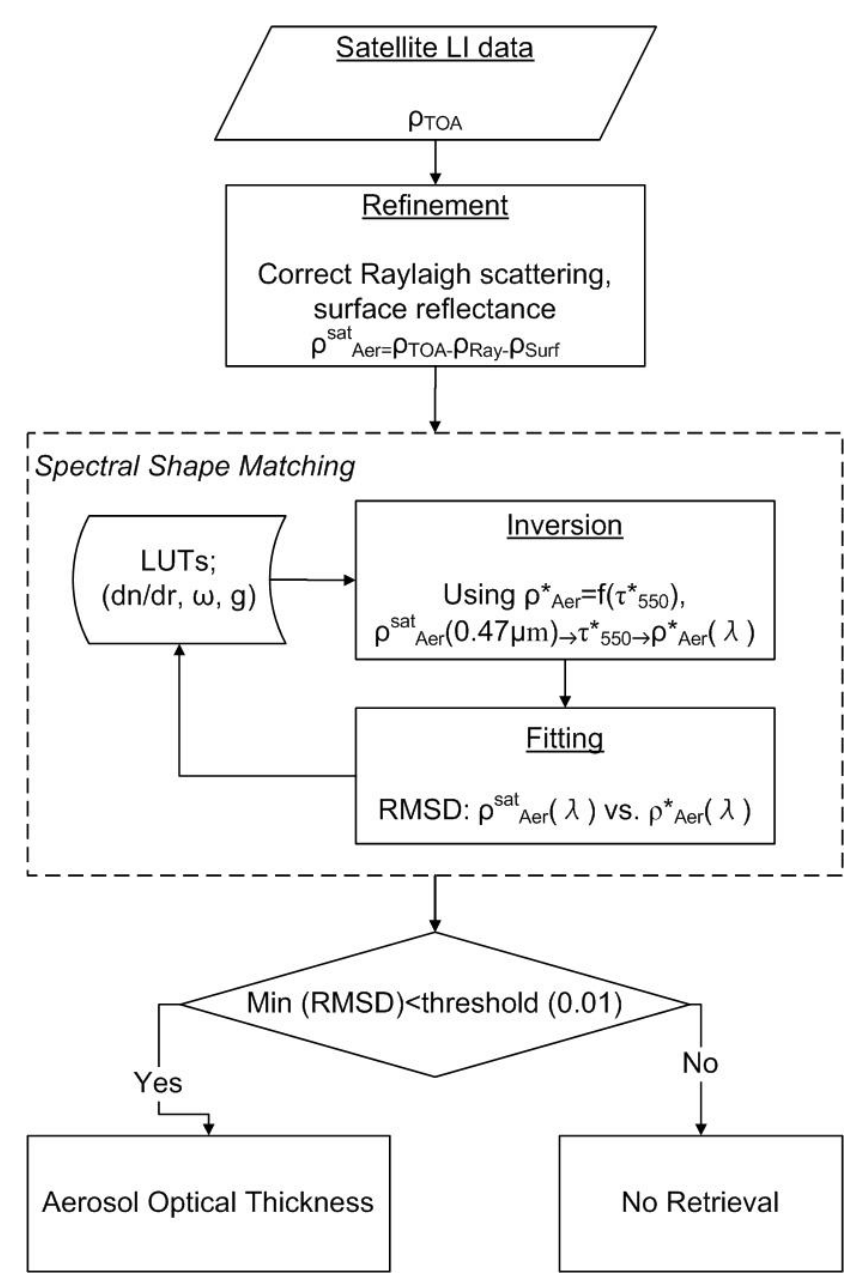

Fig. 8. Schematic diagram of aerosol retrieval.

phase function leads to an overestimation or underestimation of the AOT. To avoid this problem, recent operational algorithms (Kaufman and Tanre, 1998; Khan et al., 2005; Kokhanovsky et al., 2010) use the best combination LUT with fine and coarse mode aerosol model based on global aerosol climatology. This study is focusing on an improvement of the aerosol model to reflect local characteristics and its integration within the retrieval procedure. The aerosol retrieval based on LUTs described in Sect. 2 for the East-Asian region has been applied for MODIS data.

To determine clear sky pixels, cloud pixels were filtered out using the MODIS clear sky discrimination method (MOD35; Ackerman et al., 1998). However, the MOD35 method might not be suitable because it can mask out heavy aerosol plumes as clouds. Therefore, we used relaxed threshold values in MOD35 and the $3 \times 3$ pixel technique or inhomogeneous cloud detection (Martins et al., 2002). This is already used in the former version of the algorithm (Lee et al., 2007).
An overview of the aerosol retrieval process is presented in Fig. 8. The aerosol retrieval approach comprises the following steps for the application of LUTs, which relate AOT and aerosol reflectance:

1. The determination of the TOA reflectance by Eq. (4) at a given MODIS band.

2. The determination of aerosol reflectance $\left(\rho_{\text {Aer }}\right)$ by the subtraction of the Rayleigh ( $\left.\rho_{\text {Ray }}\right)$ and surface reflection $\left(\rho_{\text {Surf }}\right)$ from TOA reflectance $\left(\rho_{\mathrm{TOA}}\right)$ for the geometry conditions of illumination and observation; The following equation has been introduced to determine aerosol (Kaufman et al., 1997a).

$\rho_{\text {Aer }}\left(\theta_{0}, \theta_{\mathrm{S}}, \varphi\right)=\rho_{\mathrm{TOA}}\left(\theta_{0}, \theta_{\mathrm{S}}, \varphi\right)$

$-\rho_{\text {Ray }}\left(\theta_{0}, \theta_{\mathrm{S}}, \varphi\right)-\frac{T_{\mathrm{Tot}}\left(\theta_{0}\right) \cdot T_{\mathrm{Tot}}\left(\theta_{\mathrm{S}}\right) \cdot \rho_{\mathrm{Surf}}\left(\theta_{0}, \theta_{\mathrm{S}}\right)}{1-\rho_{\mathrm{Surf}}\left(\theta_{0}, \theta_{\mathrm{S}}\right) \cdot r_{\mathrm{Hem}}\left(\tau_{\mathrm{Tot}}, g\right)}$

where $\tau_{\text {Tot }}$ represent total optical thickness, $T_{\text {Tot }}$ the total atmospheric transmittance, and $r_{\mathrm{Hem}}$ the hemispheric reflectance, respectively. Reflectance due to rayleigh scattering can be determined for each pixel using an equation in the work by Bucholtz (1995). Total atmospheric transmittance contains direct and diffuse transmission for illumination and viewing geometry and is estimated from Rayleigh scattering and aerosol extinction which is performed at $0.47 \mu \mathrm{m}$. Because the blue channel has lower reflectance over dark surface, the influence of the hemispheric reflectance is less important. Detail description of the total transmittances and the hemispheric reflectance parameterizations is given in von Hoyningen-Huene et al. (2007) and Kokhanovsky et al. (2005). The polarization and aerosol-molecular scattering effects have been ignored. Thus, aerosol reflectance was calculated by subtracting Rayleigh and surface terms from TOA reflectance.

An accurate estimation of surface reflectance is therefore required for aerosol retrieval from satellite data. A linear mixing model of vegetation and bare soil spectra (von Hoyningen et al., 2003) were used to estimate surface reflectance using the following expression:

$\rho_{\text {Surf }}(\lambda)=w\left[\operatorname{NDVI}_{\mathrm{SW}} \cdot \rho_{\mathrm{Veg}}(\lambda)+\left(1-\mathrm{NDVI}_{\mathrm{SW}}\right) \cdot \rho_{\text {Soil }}(\lambda)\right]$

where $\lambda$ is the wavelength, $\rho_{\mathrm{Veg}}(\lambda)$ and $\rho_{\text {Soil }}(\lambda)$ are the spectral reflectance of "green vegetation" and "bare soil", respectively. $w$ is the empirical weighting factor for the surface reflectance level at $0.66 \mu \mathrm{m}$, which can be used tune spectral surface reflectance.

$w=\frac{\left(\rho_{\mathrm{TOA}}(0.66 \mu \mathrm{m})-\rho_{\text {ray }}(0.66 \mu \mathrm{m})\right) \times \text { slope }+0.0002 * \Theta_{\mathrm{sc}}}{\mathrm{NDVI}_{\mathrm{SW}} \cdot \rho_{\mathrm{Veg}}(0.66 \mu \mathrm{m})+\left(1-\mathrm{NDVI}_{\mathrm{SW}}\right) \cdot \rho_{\mathrm{Soil}}(0.66 \mu \mathrm{m})}(7)$

slope is determined by $\mathrm{NDVI}_{\mathrm{SW}}$ which is the vegetation index which represent the vegetation fraction in each $1 \mathrm{~km}$ resolution pixel, $\Theta_{\mathrm{sc}}$ is scattering angle. The numerator in Eq. (7) is from the collection 5 MODIS operational algorithm 
Table 3. Comparison between MSTAR AOT and AERONET AOT at Beijing $\left(116.38^{\circ} \mathrm{E}, 39.98^{\circ} \mathrm{N}\right)$ and Xianghe $\left(116.96^{\circ} \mathrm{E}, 39.75^{\circ} \mathrm{N}\right)$ stations for clean, polluted, and dust storm days.

\begin{tabular}{lcccccccc}
\hline & \multicolumn{3}{c}{ Beijing } & & \multicolumn{3}{c}{ Xianghe } \\
\cline { 2 - 4 } \cline { 7 - 8 } Case & AERONET & MSTAR & MOD04 & & AERONET & MSTAR & MOD04 \\
\hline Clean & 0.11 & 0.23 & 0.31 & & 0.17 & 0.14 & 0.06 \\
Polluted & 1.09 & 0.99 & 1.17 & & 0.99 & 0.95 & 0.98 \\
Dust & 2.49 & 2.48 & NA & & 2.38 & 2.18 & NA \\
Mean Diff. & & 0.11 & 0.14 & & & 0.04 & 0.06 \\
\hline
\end{tabular}

(Levy et al., 2007) and it is useful in surface reflectance determination because it accounts for the dependence of the surface reflection on the vegetation fraction and scattering angle. Therefore, surface reflectance at $0.47,0.55$, and $0.66 \mu \mathrm{m}$ were determined by tuned by this.

3. The determination of AOT using the spectral shape matching (SSM); The aerosol reflectance determined from step (2) is then used to derive AOT applying the LUT by the optimum aerosol model. To select the best LUT, spectral shape matching (SSM) was used. This procedure compares aerosol reflectance from satellite observation and from various LUTs at a given sun-satellite geometry. The first step in SSM is finding theoretical AOTs $\left(\tau_{550}^{*}\right)$ from a satellite estimated aerosol reflectance at $0.47 \mu \mathrm{m}\left(\rho_{\text {Aer }}^{\text {Sat }}(0.47 \mu \mathrm{m})\right)$ using a function of AOT $\left(\tau_{550}^{*}=f\left(\rho_{\text {Aer }}^{\text {Sat }}\right)\right)$. Simultaneously the theoretical aerosol reflectance $\left(\rho_{\text {Aer }}^{*}\right)$ at three channels $(0.47 \mu \mathrm{m}$, $0.55 \mu \mathrm{m}$, and $0.66 \mu \mathrm{m})$ and RMSD between $\rho_{\text {Aer }}^{\text {Sat }}$ and $\rho_{\text {Aer }}^{*}$ are determined in this step.

$\operatorname{RMSD}=\frac{1}{n} \sum_{i=1}^{n}\left(\frac{\rho_{\mathrm{Aer}}^{\mathrm{m}}\left(\lambda_{i}\right)-\rho_{\mathrm{Aer}}^{\mathrm{c}}\left(\lambda_{i}\right)}{\rho_{\mathrm{Aer}}^{\mathrm{m}}\left(\lambda_{i}\right)}\right)$

where $n$ is the number of selected wavelengths and the superscripts $\mathrm{m}$ and $\mathrm{c}$ represent the measured and calculated values, respectively. Fitting was performed at the selected wavelengths of $0.47,0.55$, and $0.66 \mu \mathrm{m}$ to minimize interference by gas absorption and surface reflectance. The best aerosol model was then determined by iteration, as shown in Fig. 8 . To find $\tau_{550}^{*}$ and $\rho_{\text {Aer }}^{*}$ for six aerosol models, the above step with each model is repeating. Finally, AOT is determined if the minimum RMSD is found. Similar approaches have been reported in previous studies (e.g. Kaufman and Tanré, 1998; Costa et al., 1999; Torricella et al., 1999; Lee et al., 2007).

\section{Results}

The AOT highly depends on the intensity of scattering as well as absorption by aerosols. This quantity can be retrieved by the algorithm described in Sect. 5. In this section, three different cases of clear sky, local polluted, and dust storm in Northeast China region are studied. For the comparison of retrieved AOT and other measurements (e.g. collection 5
MODIS L2 AOT and AERONET AOT), linear regression analysis with collocated data from long-term and multilocations was employed. There are twenty AERONET stations in East Asia as shown in Fig. 1.

Figure 9 shows the spatial distributions of the AOT at $550 \mathrm{~nm}$ (left-had side column), referred to as MODIS STAR (MSTAR) AOT, and MOD04 L2 AOT (righthand side column) for the three aerosol cases. Two different MODIS AOTs with MOD04 fine mode fraction (FMF) and the MSTAR aerosol class were plotted for clean, polluted, and dusty cases. These aerosol classes are visually depicted in the red, green, blue (RGB) color composite images. AOT values at $1 \mathrm{~km}$ resolution provided much more detail than those from the MOD04 L2 AOT at $10 \mathrm{~km}$ resolution. Although MOD04 exhibited a similar AOT distribution, it did not show clear sky and heavy dust cases well. The white pixels in the imagery are null data removed from the algorithm because the MOD04 retrieval algorithm classified AOTs $>2$ as missing data. Although MOD04 exhibited a similar AOT distribution, it was higher than the AERONET results (Table 3), probably due to the uncertainty in the surface reflectance and the aerosol model.

Table 3 shows that the MOD04 data for the polluted case agreed more closely with the AERONET data than the MSTAR data. The MOD04 AOT still overestimated the AERONET AOT $>0.08$ at Beijing, but to a lesser extent than MSTAR AOT. This overestimation/underestimation of satellite retrieved values, however, was not uniform over the region. Additionaly, the absolute mean differences indicate discrepancy in two cases (clean and polluted) equal to 0.073 based on MSTAR and 0.010 based on MOD04 datasets. Previous studies (Li et al., 2007; Mi et al., 2007) showed similar overestimation of MOD04 AOT. During polluted and dusty conditions, the absorbing aerosols can absorb solar radiation, resulting in an increase in AOT. These heavy aerosol layers showed MOD04 AOT of $1 \sim 2$ but FMF was near zero. Thus is, aerosol retrieval with a selected LUT may not be accurate. In this case, MSTAR classification of aerosol type showed red and orange color for predominantly dusty conditions. However, somewhat erroneous result over a very bright surface (e.g. desert region in the northern China) may indicate model of large dust grains (category 6). Although 


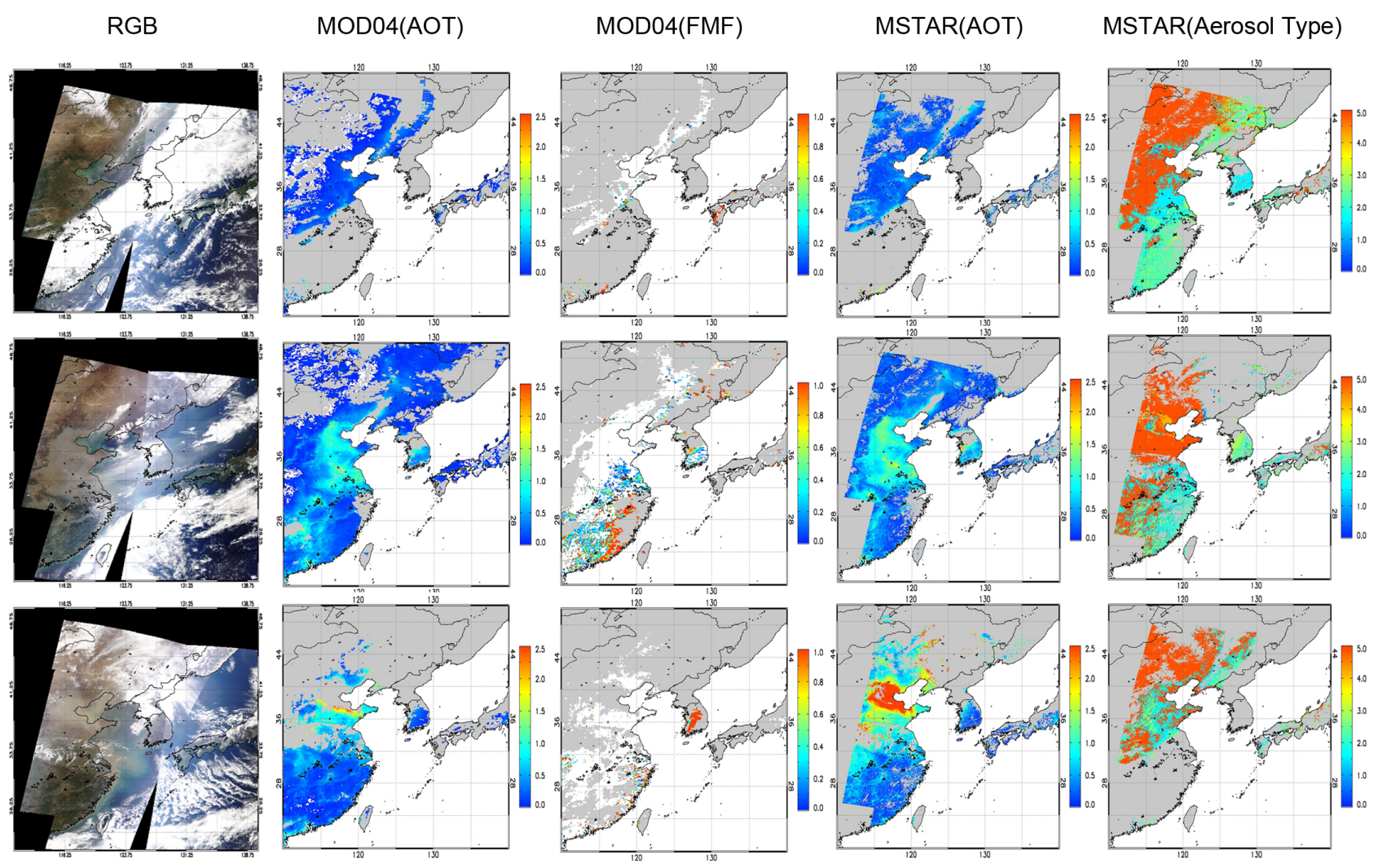

Fig. 9. MODIS RGB color composite image, MSTAR AOT, and MOD04 (collection 5) AOT from upper to lower images for (upper) a clean case on 21 September 2009, (middle) a polluted case on 23 October 2009, and (lower) an Asian dust case on 15 March 2009. Colors for MSRAR aerosol types are red (category 6), orange (category 5), yellow (category 4), green (category 3), sky-blue (category 2), and blue (category 1), respectively.

the sensitivity of TOA reflectance to aerosol type was less for smaller AOT (Fig. 6), the information from aerosol class maps must be used with caution. Improvement and verification of the retrieved aerosol class needs further investigation.

To estimate the validity of aerosol retrieval, it was necessary to compare results with independent data derived from direct radiation measurements. Figure 10 shows the correlation between MSTAR AOT and AERONET sunsky radiometer-derived AOT. For this comparison, MODIS pixels within $50 \mathrm{~km}$ of each AERONET station were selected, whereas AERONET data were taken within $30 \mathrm{~min}$ of the satellite overpass time (Ichoku et al., 2004). These spatially-averaged MSTAR AOTs and temporally-averaged AERONET AOTs were used to validate the satellitedetermined AOT retrieval. A good agreement with a linear slope of 0.94 and correlation coefficient of $R=0.92$ was found (Fig. 10a). Figure 10b shows a correlation between MOD04 AOT and AERONET sun-sky radiometer-derived AOT (linear slope $=0.78 ; R=0.87$ ), which indicates that MSTAR AOT over the study area yielded more accurate results than MOD04 AOT.

Figure 11 shows the AOT map within a $200 \mathrm{~km} \times 100 \mathrm{~km}$ rectangle, including two AERONET sites at Beijing and
Xianghe where larger AOT were observed. Table 3 compares the results for MSTAR AOT and AERONET AOT at Beijing and Xianghe sites. The mean AOT estimated from clear, polluted, and dusty conditions were $0.23,0.99$, and 2.48 , respectively, which correspond well with the AERONET AOTs (clean: 0.11, polluted: 1.09, dusty: 2.49). AOTs increased by a factor of 9-20 during polluted and dusty conditions with respect to the AOT estimated during clean periods. For the clean case, AOT values were larger compared to the AERONET results, probably due to underestimated surface reflectance separated from the satellite signal. A key result from this study is that the suggested method was sufficient to identify a clear sky or heavy aerosols in the atmosphere. As discussed in Sect. 5, the aerosol model plays an important role in the AOT retrieval, and the use of LUTs based on cluster analysis showed significant potential to retrieve AOT over land. Further analysis of the surface reflectance could increase the accuracy, even for bright surfaces. 


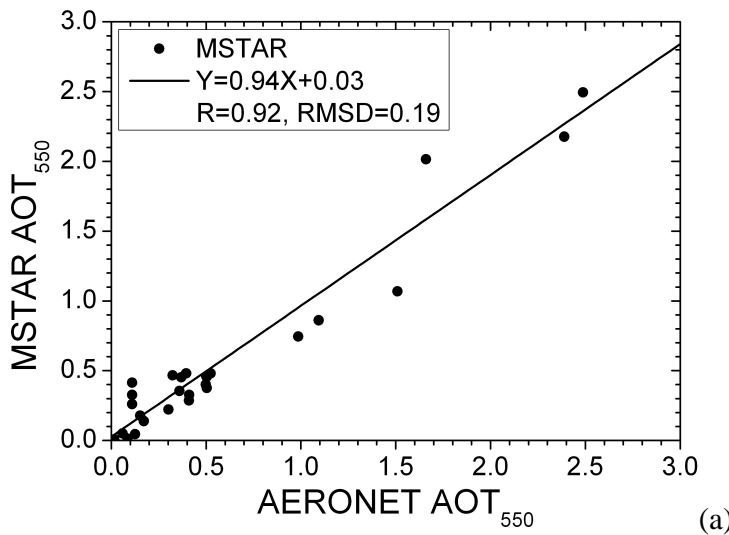

(a)

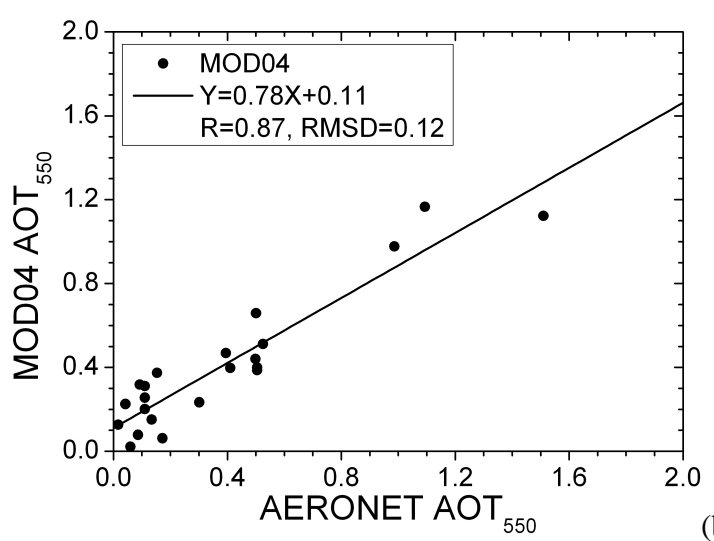

(b)

Fig. 10. Comparison of (a) MSTAR AOT and (b) MOD04 AOT with those measured by AERONET. Effective coincident data numbers are 27 for MSTAR and 22 for MOD04.

\section{Summary and conclusion}

This study presented a construction of LUTs based on statistical clusters with an AERONET database. By clustering, six aerosol types were identified, and they provided information on major aerosol types in the study area. Each aerosol class exhibited independent aerosol microphysics and optics (particle size distribution, SSA, asymmetry parameter, refractive index, and spectral extinction coefficient). Moreover, the results were quite different from known global aerosol models such as OPAC (Hess et al., 1998), indicating that specified local aerosol types are more appropriate for LUT-based aerosol retrieval.

For aerosol retrieval from satellite data, the best aerosol model selection in the algorithm was used. Our main concern was the selection and consideration of the variability of the aerosol models because a selection of an inappropriate aerosol may lead to an overestimation or underestimation of AOT. Sensitivity studies showed that the quality of the AOT retrieved from the satellite is directly related to the accuracy of the assumed aerosol optical property, such as SSA and asymmetry parameter. Uncertainty of 0.05 in SSA can cause large uncertainty in the retrieved AOT of $7.2 \%$. The AOT

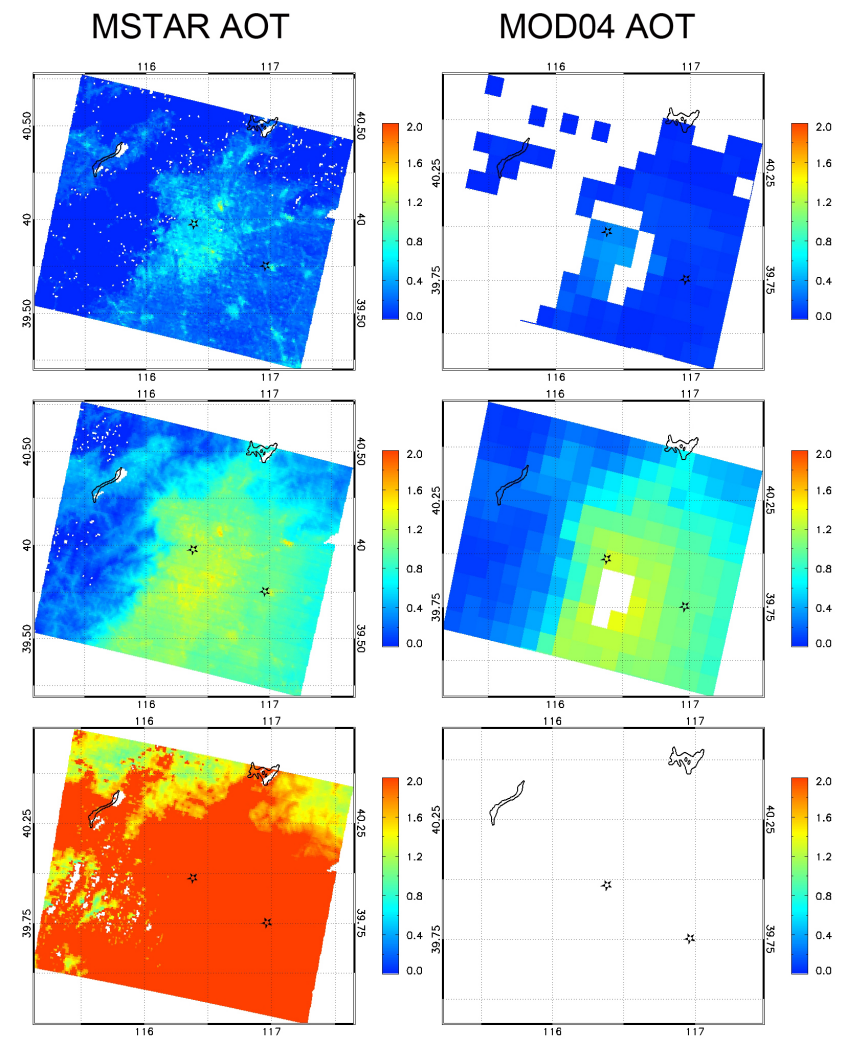

Fig. 11. Case study of clean, polluted, long-range transported dust for an urban area $\left(200 \times 100 \mathrm{~km}^{2}\right)$. Horizontal and vertical axes are longitude (degrees east) and latitude (degrees north). Note that MOD04 for the dust case cannot retrieve AOT because of the high reflection by dust aerosol.

error caused by g was substantially lower than that cause by SSA. A 5\% error in asymmetry parameter can induce an error of $\sim 4 \%$ in the retrieved AOT.

The case studies of the clean, polluted and Asian dust show the potential of the suggested methodology to retrieve AOT by successful selection of an aerosol model for the region. In general, good agreement with a linear slope of 0.94 and correlation coefficient of $R=0.92$ was observed, and this result is comparable with a correlation between MOD04 AOT and AERONET sun-sky radiometer-derived AOT (linear slope $=0.78 ; R=0.87$ ). This indicates that MSTAR AOT over the study area yielded more accurate results than MOD04 AOT. In conclusion, the aerosol model plays an important role in the AOT retrieval, and the use of LUTs based on cluster analysis showed significant potential to retrieve AOT over land. The suggested methodology needs further investigation for the case of bright surface areas. In addition to SSA and asymmetry parameter, the phase function and shape of the aerosol needs to be taken into account. Further analysis that includes those parameters could improve the accuracy of the results. 
Acknowledgements. The authors would like to thank A. A. Kokhanovsky and the anonymous reviewers for their valuable comments and suggestions to improve the quality of the paper. The research of K. H. Lee was supported by the Kyungil University Research Grant in 2009. The research of Y. J. Kim was supported by the Korea Meteorological Administration Research and Development Program under Grant RACS-20101002 through the Advanced Environmental Monitoring Research Center (ADEMRC) at Gwangju Institute of Science and Technology (GIST). The authors also would like to thank DAAC/NASA and GSFC/NASA for the use of MODIS and AERONET sun-sky radiometer data.

Edited by: A. Kokhanovsky

\section{References}

Ackerman, S. A., Strabala, K., Menzel, P., Frey, R., Moeller, C., Gumley, L., Baum, B., Seeman, S. W., and Zhang, H.: Discriminating clear-sky from cloud with MODIS. Algorithm theoretical basis document (MOD35), J. Geophys. Res., 103(D24), 3214132157, 1998.

AERONET inversion: http://aeronet.gsfc.nasa.gov/new_web/ Documents/Inversion_products_V2.pdf, last access: 4 August, 2010.

Andrews, E., Sheridan, P. J., Fiebig, M., McComiskey, A., Ogren, J. A., Arnott, P., Covert, D., Elleman, R., Gasparini, R., Collins, D., Jonsson, H., Schmid, B., and Wang, J.: Comparison of methods for deriving aerosol asymmetry parameter, J. Geophys. Res., 111, D05S04, doi:10.1029/2004JD005734, 2006.

Arimoto, R., Kim, Y. J., Kim, Y. P., Quinn, P. K., Bates, T. S., Anderson, T. L., Gong, S., Uno, I., Chin, M., Huebert, B. J., Clarke, A. D., Shinozuka, Y., Weber, R. J., Anderson, J. R., Guazzotti, S. A., Sullivan, R. C., Sodeman, D. A., Prather, K. A., and Sokolik, I. N.: Characterization of Asian Dust during ACE-Asia, Global and Planet. Change, 52, 23-56, doi:10.1016/j.gloplacha.2006.02.013, 2006.

Bucholtz, A.,: Rayleigh-scattering calculations for the terrestrial atmosphere, Appl. Optics, 34, 2765-2773, 1995.

Costa, M. J., Cervino, M., Cattani, E., Torricella, F., Levizzani, V., and Silva, A. M.: Aerosol optical thickness and classification: use of METEOSAT, GOME and modeled data., in: EOS-SPIE International Symposium on Remote Sensing, edited by: Russell, J. E., Proceedings of SPIE, vol. 3867, Satellite Remote Sensing of Clouds and the Atmosphere IV, 268-279, 1999.

d'Almeida, G. A., Koepke, P., and Shettle, E. P.: Atmospheric aerosols: Global climatology and radiative characteristics, A Deepak Publishing, Hampton, Virginia, 561 pp., 1991.

de Castanho, A. A. D., Martins, J. V., and Artaxo, P.: MODIS aerosol optical depth retrievals with high spatial resolution over an urban area using the critical reflectance, J. Geophys. Res., 113, D02201, doi:10.1029/2007JD008751, 2008.

Diner, D., Beckert, J., Reilly, T. H., Bruegge, C., Conel, J. E., Kahn, R. A., Martonchik, J., Ackerman, T. P., Davies, R., Gerstl, S. A. W., Gordon, H., Muller, J.-P., Myneni, R. B., Sellers, P. J., Pinty, B., and Verstraete, M. M.: Multi-angle Imaging SpectroRadiometer (MISR) instrument description and experiment overview, IEEE T. Geosci. Remote, 36(4), 1072-1087, 1998.
Dubovik, O. and King, M. D.: A flexible inversion algorithm for retrieval of aerosol optical properties from sun and sky radiance measurements, J. Geophys. Res., 105, 20673-20696, 2000.

Dubovik, O., Smirnov, S., Holben, B. N., King, M. D., Kaufman, Y. J., Eck, T. F., and Slutsker, I.: Accuracy assessment of aerosol optical properties retrieved from AERONET sun and sky radiance measurements, J. Geophys. Res., 105(D8), 9791-9806, 2000.

Dubovik, O., Holben, B. N., Eck, T. F., Smirnov, A., Kaufman, Y. J., King, M. D., Tanré, D., and Slutsker, I.: Variability of absorption and optical properties of key aerosol types observed in worldwide locations, J. Atmos. Sci., 59, 590-608, 2002a.

Dubovik, O., Holben, B. N., Lapyonok, T., Sinyuk, A., Mishchenko, M. I., Yang, P., and Slutsker, I.: Non-spherical aerosol retrieval method employing light scattering by spheroids, Geophys. Res. Lett., 10, 29(10), doi:10.1029/2001GL014506, $2002 b$.

Gordon, H. R. and Wang, M.: Retrieval of water-leaving radiance and aerosol optical thickness over the oceans with Sea-WiFS: A preliminary algorithm, Appl. Optics, 33, 443-452, 1994.

Hansen, J. E.: Exact and approximate solutions for multiple scattering by cloudy and hazy planetary atmospheres, J. Atmos. Sci., 26, 478-487, 1969.

Hess, M., Koepke, P., and Schult, I.: Optical properties of aerosols and clouds: The software package OPAC, B. Am. Metol. Soc., 79, 831-844, 1998.

Holben, B. N., Eck, T. F., Slutsker, I., Tanré, D., Buis, J. P., Setzer, A., Vermote, E., Reagan, J. A., Kaufman, Y. J., Nakajima, T., Lavenu, F., Jankowiak, I., and Smirnov, A.: AERONET - A federated instrument network and data archive for aerosol characterization, Remote Sens. Environ., 66, 1-16, 1998.

Holben, B., Eck, T. F., Slutsker, I., Smirnov, A., Sinyuk, A., Schafer, J., Giles, D., and Dubovik, O.: Aeronet's Version 2.0 quality assurance criteria, Proc. SPIE, 6408(64080Q), doi:10.1117/12.706524, 2006.

Ichoku, C., Kaufman, Y. J., Remer, L. A., and Levy, R: Global aerosol remote sensing from MODIS, Adv. Space Res., 34, 820827, 2004.

IPCC: Climate Change: The Science Basis, Cambridge Univ. Press, New York, 870 pp., 2007.

Jeong, M. J., Li, Z., Chu, D. A., and Tsay, S.-T.: Quality and compatibility analyses of global aerosol products derived from the advanced very high resolution radiometers and the moderate imaging spectroradiometer, J. Geophys. Res., 110, D10S09, doi:10.1029/2004JD004648, 2005.

Kahn, R. A., Gaitley, B. J., Martonchik, J. V., Diner, D. J., Crean, K. A., and Holben, B.: Multiangle Imaging Spectroradiometer (MISR) global aerosol optical depth validation based on 2 years of coincident Aerosol Robotic Network (AERONET) observations, J. Geophys. Res. 110, D10S04, doi:10.1029/2004JD004706, 2005.

Katsev, I. L., Prikhach, A. S., Zege, E. P., Grudo, J. O., and Kokhanovsky, A. A.: Speeding up the aerosol optical thickness retrieval using analytical solutions of radiative transfer theory, Atmos. Meas. Tech., 3, 1403-1422, doi:10.5194/amt-3-14032010, 2010.

Kaufman, L. and Rousseeuw, P. J.: Finding Groups in Data: An Introduction to Cluster Analysis, John Wiley \& Sons, Inc., New York, 1990. 
Kaufman, Y. J. and Tanré, D.: Algorithm For remote sensing of tropospheric aerosol from MODIS, algorithm theoretical basis document, ATBD-MOD-02, NASA Goddard Space Flight Center, 1998.

Kaufman, Y. J., Wald, A. E., Remer, L. A., Gao, B. C., Li, R.-R., and Flynn, L.: The MODIS 2.1-mm channel correlation with visible reflectance for use in remote sensing of aerosol, IEEE T. Geosci. Remote, 35, 1286-1298, 1997a.

Kaufman, Y. J., Tanré, D., Remer, L., Vermote, E. F., Chu, A., and Holben, B. N.: Operational remote sensing of tropospheric aerosol over the land from EOS-MODIS, J. Geophys. Res., 102(14), 17051-17068, 1997b.

King, D. M., Kaufman, Y. J., Tanre, D., and Nakajima, T.: Remote sensing of tropospheric aerosols from space: past, present, and future, B. Am. Meterol. Soc., 80(11), 2229-2259, doi:10.1175/1520-0477, 1999.

Kinne, S., Schulz, M., Textor, C., Guibert, S., Balkanski, Y., Bauer, S. E., Berntsen, T., Berglen, T. F., Boucher, O., Chin, M., Collins, W., Dentener, F., Diehl, T., Easter, R., Feichter, J., Fillmore, D., Ghan, S., Ginoux, P., Gong, S., Grini, A., Hendricks, J., Herzog, M., Horowitz, L., Isaksen, I., Iversen, T., Kirkevåg, A., Kloster, S., Koch, D., Kristjansson, J. E., Krol, M., Lauer, A., Lamarque, J. F., Lesins, G., Liu, X., Lohmann, U., Montanaro, V., Myhre, G., Penner, J., Pitari, G., Reddy, S., Seland, O., Stier, P., Takemura, T., and Tie, X.: An AeroCom initial assessment - optical properties in aerosol component modules of global models, Atmos. Chem. Phys., 6, 1815-1834, doi:10.5194/acp-6-1815-2006, 2006.

Kokhanovsky, A. A. and de Leeuw, G.: Satellite aerosol remote sensing over land, Springer-Praxis, 379 pp., 2009.

Kokhanovsky, A. A., Mayer, B., and Rozanov, V. V.: A parameterization of the diffuse transmittance and reflectance for aerosol remote sensing problems, Atmos. Res., 73(1-2), 37-43, doi:10.1016/j.atmosres.2004.07.004, 2005.

Kokhanovsky, A. A., Breon, F. M., Cacciari, A., Carboni, E., Diner, D., Di Nicolantonio, W., Grainger, R. G., Grey, W. M. F., Höller, R., Lee, K. H., Li, Z., North, P. R. J., Sayer, A., Thomas, G., and von Hoyningen-Huene, W.: Aerosol remote sensing over land: satellite retrievals using different algorithms and instruments, Atmos. Res., 85(3-4), 379-394, doi:10.1016/j.atmosres.2007.02.008, 2007.

Kokhanovsky, A. A., Curer, R. L., de Leeuw, G., Grey, W. M. F., Lee, K. H., Bennouna, Y., Shoemaker, R., North, P. R. J.: The inter-comparison of AATSR dual view aerosol optical thickness retrievals with results from various algorithms and instruments, Int. J. Remote Sens., 30(17), doi:10.1080/01431160802578012, 2009.

Kokhanovsky, A. A., Deuzé, J. L., Diner, D. J., Dubovik, O., Ducos, F., Emde, C., Garay, M. J., Grainger, R. G., Heckel, A., Herman, M., Katsev, I. L., Keller, J., Levy, R., North, P. R. J., Prikhach, A. S., Rozanov, V. V., Sayer, A. M., Ota, Y., Tanré, D., Thomas, G. E., and Zege, E. P.: The inter-comparison of major satellite aerosol retrieval algorithms using simulated intensity and polarization characteristics of reflected light, Atmos. Meas. Tech., 3, 909-932, doi:10.5194/amt-3-909-2010, 2010.

Lee, K. H., Kim, Y. J., and von Hoyningen-Huene, W.: Estimation of aerosol optical thickness over northeast Asia from SeaWiFS data during the 2001 ACE-Asia IOP, J. Geophys. Res., 109, D19S16, doi:10.1029/2003JD004126, 2004.
Lee, K. H., Kim, Y. J., von Hoyningen-Huene, W., and Burrows, J. P.: Spatio-temporal variability of atmospheric aerosol from MODIS data over northeast Asia in 2004, Atmos. Environ., 41(19), 3959-3973. doi:10.1016/j.atmosenv.2007.01.048, 2007.

Lee, K. H., Li, Z., Kim, Y. J., and Kokhanovsky, A.: Aerosol monitoring from satellite observations: a history of three decades, Atmospheric and Biological Environmental Monitoring, edited by: Kim, Y. J., Platt, U., Gu, M. B., and Iwahashi, H., Springer, 13-38, doi:10.1007/978-1-4020-9674-7, 2009.

Levy, R. C., Remer, L. A., Mattoo, S., Vermote, E. F., and Kaufman, Y. J.: Second-generation operational algorithm: retrieval of aerosol properties over land from inversion of moderate resolution imaging spectroradiometer spectral reflectance, J. Geophys. Res., 112, D13211, doi:10.1029/2006JD007811, 2007.

Li, C., Lau, A. K. H., Mao, J., and Chu, A.: Retrieval, validation, and application of the 1-km aerosol optical depth from MODIS measurements over Hong Kong, IEEE T. Geosci. Remote, 43(11), 2650-2658, 2005.

Li, Z., Niu, F., Lee, K.-H., Xin, J., Hao, W.-M., Nordgren, B., Wang, Y., and Wang, P.,: Validation and understanding of moderate resolution imaging spectroradiometer aerosol products (C5) using ground-based measurements from the handheld Sun photometer network in China, J. Geophys. Res., 112, D22S07, doi:10.1029/2007JD008479, 2007.

Liu, L. and Mishchenko, M. I.: Toward unified satellite climatology of aerosol properties: direct comparisons of advanced level 2 aerosol products, J. Quant. Spectrosc. Ra., 109(14), 2376-2385, doi:10.1016/j.jqsrt.2008.05.003, 2008.

Martins, J. V., Tanré, D., Remer, L., Kaufman, Y., Mattoo, S., and Levy, R.: MODIS cloud screening for remote sensing of aerosols over oceans using spatial variability, Geophys. Res. Lett., 29(12), 8009, doi:10.1029/2001GL013252, 2002.

Mi, W., Li, Z., Xia, X., Holben, B., Levy, R., Zhao, F., Chen, H., and Cribb, M.: Evaluation of the moderate resolution imaging spectroradiometer aerosol products at two aerosol robotic network stations in China, J. Geophys. Res., 112, D22S08, doi:10.1029/2007JD008474, 2007.

Mishchenko, M. I. and Travis, L. D.: Capabilities and limitations of a current FORTRAN implementation of the T-matrix method for randomly oriented, rotationally symmetric scatterers, J. Quant. Spectrosc. Ra., 60, 309-324, 1998.

Mishchenko, M. I., Geogdzhayev, I. V., Cairns, B., Carlson, B. E., Chowdhary, J., Lacis, A. A., Liu, L., Rossow, W. B., and Travis, L. D.: Past, present, and future of global aerosol climatologies derived from satellite observations: a perspective, J. Quant. Spectrosc, Ra., 106(1-3), 325-347, doi:10.1016/j.jqsrt.2007.01.007, 2007.

Omar, A. H., Won, J.-G., Winker, D. M., Yoon, S.-C., Dubovik, O., and McCormick, M. P.: Development of global aerosol models using cluster analysis of Aerosol Robotic Network (AERONET) measurements, J. Geophys. Res., 110, D10S14, doi:10.1029/2004JD004874, 2005.

Rao, C. R. N., McClain, E. P., and Stowe, L. L.: Remote sensing of aerosols over the oceans using AVHRR data theory, practice, and applications, Int. J. Remote Sens., 10(4-5), 743-749, 1989.

Ricchiazzi, P., Yang, S., Gautier, C., and Sowle, D.: SBDART: A research and teaching software tool for plane-parallel radiative transfer in the Earth's atmosphere, B. Am. Meteorol. Soc., 79(10), 2101-2114, 1998. 
Sheridan, P. J., Delene, D. J., and Ogren, J. A.: Four years of continuous surface aerosol measurements from the department of energy's atmospheric radiation measurement program southern great plains cloud and radiation testbed site, J. Geophys. Res., 106(D18), 20735-20748, 2001.

Shettle, E. P. and Fenn, R. W.: Models for the aerosols of the lower atmosphere and the effects of humidity variations on their optical properties, AFGLTR-79-0214, US Air Force Geophysics Laboratory, Hanscom Air Force Base, Massachusetts, 1979.

Song, C. H., Park, M. E., Lee, K. H., Ahn, H. J., Lee, Y., Kim, J. Y., Han, K. M., Kim, J., Ghim, Y. S., and Kim, Y. J.: An investigation into seasonal and regional aerosol characteristics in East Asia using model-predicted and remotely-sensed aerosol properties, Atmos. Chem. Phys., 8, 6627-6654, doi:10.5194/acp8-6627-2008, 2008.

Soufflet, V., Tanré, D., Royer, A., and O'Neill, N. T.: Remote sensing of aerosols over boreal forest and lake water from AVHRR data, Remote Sens Environ, 60, 22-34, 1997.

Stowe, L. L.: Cloud and aerosol products at NOAA/NESDIS, Paleogeogr. Paleoclimatol. Paleoecol., 90, 25-32, 1991.

Streets, D. G., Bond, T. C., Carmichael, G. R., Fernandes, S. D., Fu, Q., He, D., Klimont, Z., Nelson, S. M., Tsai, N. Y., Wang, M. Q., Woo, J.-H., and Yarber, K. F.: An inventory of gaseous and 10 primary aerosol emissions in Asia in the year 2000, J. Geophys. Res., 108, 8809, doi:10.1029/2002JD003093, 2003.
Torricella, F., Cattani, E., Cervino, M., Guzzi, R., and Levoni, C.: Retrieval of aerosol properties over the ocean using global ozone monitoring experiment measurements: method and applications to test cases, J. Geophys. Res., 104(D10), 12085-12098, 1999.

von Hoyningen-Huene, W., Freitag, M., and Burrows, J. B.: Retrieval of aerosol optical thickness over land surfaces from topof-atmosphere radiance, J. Geophys. Res., 108(D9), 4260, 2003. von Hoyningen-Huene, W., Kokhanovsky, A. A., Wuttke, M. W., Buchwitz, M., Noël, S., Gerilowski, K., Burrows, J. P., Latter, B., Siddans, R., and Kerridge, B. J.: Validation of SCIAMACHY top-of-atmosphere reflectance for aerosol remote sensing using MERIS L1 data, Atmos. Chem. Phys., 7, 97-106, doi:10.5194/acp-7-97-2007, 2007.

von Hoyningen-Huene, W., Yoon, J., Vountas, M., Istomina, L. G., Rohen, G., Dinter, T., Kokhanovsky, A. A., and Burrows, J. P.: Retrieval of spectral aerosol optical thickness over land using ocean color sensors MERIS and SeaWiFS, Atmos. Meas. Tech. Discuss., 3, 2107-2164, doi:10.5194/amtd-3-2107-2010, 2010.

Wenig, M., Spichtinger, N., Stohl, A., Held, G., Beirle, S., Wagner, T., Jähne, B., and Platt, U.: Intercontinental transport of nitrogen oxide pollution plumes, Atmos. Chem. Phys., 3, 387-393, doi:10.5194/acp-3-387-2003, 2003. 